\title{
Integrating ICT into University Curriculum: A Proposal for the Faculty of Arts, University of Dhaka, Bangladesh
}

\author{
Nafiz Zaman Shuva \\ Department of Information Science \& Library Management, \\ University of Dhaka, Dhaka-1000, Bangladesh
}

\author{
nafiz z@hotmail.com
}

\begin{abstract}
Purpose: The core purpose of the article is to describe the ways to integrate ICT into the departmental curriculum of Faculty of Arts, University of Dhaka as well as to identify the problems that hinder the integration process. Design/methodology/approach: The paper reviews the literature related to ICT integration into the academic curriculum, benefits of ICT integration and its related aspect. A survey was conducted by the researcher to find out the existing status of ICT integration in the curriculum of departments of the Faculty of Arts, University of Dhaka. Findings: It is found that most of the departments of the Faculty of Arts do not have ICT related courses in their syllabus. It is also found that most of the departments lack ICT related infrastructural facilities as well as there is no ICT equipment in the class room. This paper demonstrates the ways to integrate ICT into the curriculum of Faculty of Arts, University of Dhaka, which could also be taken to integrate ICT into the curriculum of other faculties. It presents a sample ICT curriculum for university students. Finally recommendation is made to integrate ICT into the academic curriculum of the universities in Bangladesh.
\end{abstract}

Keywords: ICT into curriculum, benefits of ICT in education, ICT for Faculty of Arts, University of Dhaka, Bangladesh, ICT Curriculum integration proposal.

\section{Introduction}

Educational systems around the world are under increasing pressure to use the new information and communication technologies (ICT) to teach students the knowledge and skills they need in the 21 st century. The challenge confronting our educational systems is how to transform the curriculum and teaching-learning process to provide students with the skills to function effectively in this dynamic, information-rich, and continuously changing environment. ICTs provide an array of powerful tools that may help in transforming the present isolated, teacher-centred and text-bound

Material published as part of this publication, either on-line or in print, is copyrighted by the Informing Science Institute. Permission to make digital or paper copy of part or all of these works for personal or classroom use is granted without fee provided that the copies are not made or distributed for profit or commercial advantage AND that copies 1) bear this notice in full and 2) give the full citation on the first page. It is permissible to abstract these works so long as credit is given. To copy in all other cases or to republish or to post on a server or to redistribute to lists requires specific permission and payment of a fee. Contact 0HPublisher@InformingScience.org to request redistribution permission. classrooms into rich, student-focused, interactive knowledge environments. To meet these challenges, learning institutions must embrace the new technologies and appropriate ICT tools for learning. They must also move towards the goal of transforming the traditional paradigm of learning (Omwenga, 2005).

The experience of introducing different ICTs in the classroom and other educational settings all over the world over 
the past several decades suggests that the full realization of the potential educational benefits of ICTs is not automatic. The effective integration of ICTs into the educational system is a complex, multifaceted process that involves not just technology — indeed, given enough initial capital, getting the technology is the easiest part! - but also curriculum and pedagogy, institutional readiness, teacher competencies, and long-term financing, among others (Tinio, 2003).

ICT status of Bangladesh is not praiseworthy. Only $1.36 \%$ population nationally reported access to computers (BBS, 2005) which shows the low use of computers by the people. Use of computer began in Bangladesh in the 1960s and assumed wider dimension in the nineties. The first computer in Bangladesh (erstwhile East Pakistan) was installed at the atomic energy centre, Dhaka of Pakistan Atomic Energy Commission in 1964. It was an IBM Mainframe Computer of 1620 series. The main use of the machine was resolving complicated mathematical calculations in different research works. Though the use of Internet worldwide spread rapidly in 1990, Bangladesh joined the bandwagon much later. Use of Internet in the country started in 1995 for the first time in a limited way through offline e-mail. VSAT (Very Small Aperture Terminal) was first set up in 1996 for Internet purpose. PCs became easily available due to its easy use and cheapness in price. As a result, use of PCs started to increase in Bangladesh mainly since the last part of the eighties, especially in education and business concerns. However, wider use of computer in Bangladesh accelerated from the mid-nineties (Banglapedia, 2006).

Bangladesh University of Engineering and Technology (BUET) first introduced the formal education in Information Technology in 1984 by launching the Masters program in Computer Science and Engineering. Undergraduate courses started from 1986 with the first intake in 1987. University of Dhaka started one year Masters program in Computer Science in 1993. Besides, some Computer related courses such as Microprocessors and programming languages are taught in Applied Physics and Electronics department (Rahman, 2008).

In the annual session of June 2001, The University of Dhaka Senate established the Institute of Information Technology (IIT) by converting the erstwhile Computer Centre (Estd. in 1985). Institute of Information Technology creates efficient manpower in information technology and provides Network Service to the University. The Institute offers Master in Information Technology (MIT) and Post Graduate Diploma in Information Technology (PGDIT) (University of Dhaka Prospectus, 2008). However due to lack of infrastructural facilities, funds, ICT skills and effective initiatives ICT situation at various departments of the University of Dhaka and in the administrative process is not worth mentioning.

\section{Benefits of ICT in Education}

Kok (2006) in his paper mentioned the reasons for the application of ICTs in education given by Hepp et al (2004):

i) A new society requires new skills: Due to the fact that ICTs are the preeminent tools for information processing, new generations need to become competent in their use, should acquire the necessary skills, and therefore must have access to computers and networks during their school life.

ii) Productivity enhancement: Schools are knowledge-handling institutions; therefore, ICTs should be fundamental management tools on all levels of an educational system, from classrooms to ministries.

iii) A quest for quality learning: Schools should profoundly revise present teaching practices and resources to create more effective learning environments and improve life-long learning skills and habits in their students. 
Kok (2006) also mentioned the following positive effects of ICT on student in education identified by Papert, S. (1997):

i) enhanced motivation and creativity when confronted by the new learning environments

ii) a greater disposition to research and problem-solving focused on real social situations

iii) more comprehensive assimilation of knowledge in the interdisciplinary ICT environment

iv) systematic encouragement of collaborative work between individuals and groups

v) ability to generate knowledge

vi) capacity to cope with rapidly changing, complex, and uncertain environments

vii) vii)new skills and abilities fostered through technological literacy

Barron et al. (2002) report the following benefits of integrating technology into education:

1. Promotes active learning

2. Promotes critical thinking

3. Offers diversity and self-paced learning and individual growth

4. Motivates and inspires students by making learning exciting and relevant

5. Provides flexibility for students with special needs

6. Promotes cooperative learning and increases teacher-student interaction

7. Enhances communication skills

8. Supplies information through multi sensory channels (supporting students with various learning styles and

9. Helps students to build cultural bridges.

Valdez (2004) as cited by Kajuna (2009) observes that technology offers many opportunities to improve learning and that it has the potential to provide people in their own homes and work settings with access to knowledge and learning resources possible until recently only in very large universities. Furthermore, he argues that technology has the potential to make everyone a producer of original knowledge that can be shared with the world at very little cost. Franklin (2000), as cited by Blankson (2004) observes that technology in education may promote new learning environments in which enquiry and problem solving increase student achievement. Instructor may use technology to assist students to develop deeper understanding of concepts by engaging students in active learning practices.

\section{Current Status of ICT related Courses in the Curriculum of Faculty of Arts, University of Dhaka}

On the first day of July 1921 the University of Dhaka opened its doors to students with Sir P.J. Hartog as the first Vice-Chancellor of the University. The University started its activities with 3 Faculties, 12 Departments, 60 teachers, 877 students and 3 dormitories (Halls of Residence) for the students. At present the University consists of 13 Faculties, 66 Departments, 8 Institutes, and more than 30 Research Centres. The number of students and teachers has risen to about 33,000 and 1,500 respectively. (University of Dhaka Prospectus, 2008)

Established in 1921, the Faculty of Arts, one of the largest faculties of the university, consists of fifteen Departments. The academic activities of these departments are conducted by the Faculty of Arts. Table 1 shows the departments that are under the faculty of arts. 
Table 1: Departments of the Faculty of Arts

\begin{tabular}{|c|c|c|c|c|}
\hline $\begin{array}{l}\text { SL. } \\
\text { No. }\end{array}$ & Name of the Department & $\begin{array}{l}\text { Year of } \\
\text { Establishment }\end{array}$ & $\begin{array}{l}\text { No. of Current } \\
\text { Students }\end{array}$ & $\begin{array}{l}\text { No. of Faculty } \\
\text { Members (in- } \\
\text { cluding part time } \\
\text { faculty) }\end{array}$ \\
\hline 1. & Department of Bengali & 1921 & 783 & 28 \\
\hline 2. & Department of English & 1921 & 693 & 35 \\
\hline 3. & Department of Arabic & 1921 & 640 & 19 \\
\hline 4. & $\begin{array}{l}\text { Department of Persian } \\
\text { Language \& Literature } \\
(1921 / 2007)\end{array}$ & $1921 / 2007 *$ & 152 & 10 \\
\hline 5. & Department of Urdu & $1921 / 2007^{*}$ & 147 & 12 \\
\hline 6. & Department of Sanskrit & $1921 / 2007^{*}$ & 238 & 14 \\
\hline 7. & $\begin{array}{l}\text { Department of Pali and } \\
\text { Buddhist Studies }\end{array}$ & $1921 / 2007^{*}$ & 99 & 13 \\
\hline 8. & Department of History & 1921 & 616 & 42 \\
\hline 9. & Department of Philosophy & 1921 & 785 & 27 \\
\hline 10. & $\begin{array}{l}\text { Department of Islamic } \\
\text { Studies }\end{array}$ & 1921 & 652 & 27 \\
\hline 11. & $\begin{array}{l}\text { Department of Islamic His- } \\
\text { tory and Culture }\end{array}$ & 1948 & 618 & 32 \\
\hline 12. & $\begin{array}{l}\text { Department of Information } \\
\text { Science \& Library Man- } \\
\text { agement }\end{array}$ & 1959 & 471 & 17 \\
\hline 13. & $\begin{array}{l}\text { Department of Theatre and } \\
\text { Music }\end{array}$ & 1994 & - & 20 \\
\hline 14. & Department of Linguistics & 1992 & 259 & 19 \\
\hline 15. & $\begin{array}{l}\text { Department of World Re- } \\
\text { ligions }\end{array}$ & 1999 & 99 & 15 \\
\hline
\end{tabular}

** Source: Compiled mainly from the Annual Report of the University of Dhaka, 2006-2007.

* In 1921 Department of Sanskrit and Pali was established as one department. In 2007 Department of Sanskrit and Pali become two independent departments. One is Department of Sanskrit and other is Department of Pali and Buddhist Studies. Similarly Department of Persian and Urdu was established in 1921 which became two separate departments in 2007.

The researcher visited 15 departments of the Faculty of Arts to assess the current status of ICT integration into the syllabus of those departments. Table 2 shows the findings of that visit: 
Table 2: ICT related courses in the existing syllabus of the departments of the Faculty of Arts

\begin{tabular}{|c|c|c|c|c|}
\hline $\begin{array}{l}\text { SL. } \\
\text { No. }\end{array}$ & Name of the Department & $\begin{array}{c}\text { Degrees } \\
\text { Conferred }\end{array}$ & $\begin{array}{c}\text { ICT related } \\
\text { Courses in the } \\
\text { Existing Syllabus }\end{array}$ & $\begin{array}{c}\text { Marks } \\
\text { Distribution }\end{array}$ \\
\hline 1. & Department of Bengali & $\begin{array}{l}\text { B.A. (Honors), } \\
\text { Masters, M.Phil, } \\
\text { PhD }\end{array}$ & No & - \\
\hline 2. & Department of English & $\begin{array}{l}\text { B.A. (Honors), } \\
\text { Masters, M.Phil, } \\
\text { PhD }\end{array}$ & No & - \\
\hline 3. & Department of Arabic & $\begin{array}{l}\text { B.A. (Honors), } \\
\text { Masters, M.Phil, } \\
\text { PhD }\end{array}$ & No & - \\
\hline 4. & $\begin{array}{l}\text { Department of Persian } \\
\text { Language \& Literature }\end{array}$ & $\begin{array}{l}\text { B.A. (Honors), } \\
\text { Masters, M.Phil, } \\
\text { PhD }\end{array}$ & $\begin{array}{c}\text { No } \\
\text { (Planning to intro- } \\
\text { duce soon) }\end{array}$ & - \\
\hline 5. & Department of Urdu & $\begin{array}{l}\text { B.A. (Honors), } \\
\text { Masters, M.Phil, } \\
\text { PhD }\end{array}$ & $\begin{array}{l}\text { Course no. 106- } \\
\text { Fundamentals of } \\
\text { Information and } \\
\text { Communication } \\
\text { Technologies }\end{array}$ & $\begin{array}{c}1^{\text {st }} \text { Year } 2^{\text {nd }} \text { Se- } \\
\text { mester of } \\
\text { B.A.(Honors) - } \\
100 \text { Marks (The- } \\
\text { ory) }\end{array}$ \\
\hline 6. & Department of Sanskrit & $\begin{array}{l}\text { B.A. (Honors), } \\
\text { Masters, M.Phil, } \\
\text { PhD }\end{array}$ & $\begin{array}{c}\text { Course no. 209- } \\
\text { Computer Science }\end{array}$ & $\begin{array}{l}2^{\text {nd }} \text { Year } 3^{\text {rd }} \text { Se- } \\
\text { mester B.A. } \\
\text { (Honors)-100 } \\
\text { Marks (Theory) }\end{array}$ \\
\hline 7. & $\begin{array}{l}\text { Department of Pali and } \\
\text { Buddhist Studies }\end{array}$ & $\begin{array}{l}\text { B.A. (Honors), } \\
\text { Masters, M.Phil, } \\
\text { PhD }\end{array}$ & $\begin{array}{c}\text { Course no.205 } \\
\text { Computer Science }\end{array}$ & $\begin{array}{c}2^{\text {nd }} \text { Year } 2^{\text {nd }} \text { Se- } \\
\text { mester B.A. } \\
\text { (Honors)-100 } \\
\text { Marks (Theory) }\end{array}$ \\
\hline 8. & Department of History & $\begin{array}{l}\text { B.A. (Honors), } \\
\text { Masters, M.Phil, } \\
\text { PhD }\end{array}$ & No & - \\
\hline 9. & Department of Philosophy & $\begin{array}{l}\text { B.A. (Honors), } \\
\text { Masters, M.Phil, } \\
\text { PhD }\end{array}$ & No & - \\
\hline \multirow[t]{3}{*}{10.} & \multirow[t]{3}{*}{$\begin{array}{l}\text { Department of Islamic } \\
\text { Studies }\end{array}$} & \multirow[t]{3}{*}{$\begin{array}{l}\text { B.A. (Honors), } \\
\text { Masters, M.Phil, } \\
\text { Ph.D }\end{array}$} & $\begin{array}{l}\text { i) Course no. 306- } \\
\text { Computer Literacy }\end{array}$ & $\begin{array}{c}3^{\text {rd }} \text { Year } 6^{\text {th }} \text { Se- } \\
\text { mester of B.A. } \\
\text { (Honors)-100 } \\
\text { Marks (Theory \& } \\
\text { Practical) }\end{array}$ \\
\hline & & & $\begin{array}{l}\text { ii) Course no. } 403- \\
\text { Computer Literacy }\end{array}$ & $\begin{array}{l}4^{\text {th }} \text { Year } 7^{\text {th }} \text { Se- } \\
\text { mester of B.A. } \\
\text { (Honors)- } 100 \\
\text { Marks (Theory \& } \\
\text { Practical) }\end{array}$ \\
\hline & & & $\begin{array}{l}\text { iii) Course no. } 509 \\
\text { (B)- Computer } \\
\text { Literacy }\end{array}$ & $\begin{array}{c}\text { Masters-100 } \\
\text { Marks (Theory \& } \\
\text { Practical) } \\
\end{array}$ \\
\hline 11. & $\begin{array}{l}\text { Department of Islamic } \\
\text { History and Culture }\end{array}$ & $\begin{array}{l}\text { B.A. (Honors), } \\
\text { Masters, M.Phil, } \\
\text { PhD }\end{array}$ & No & - \\
\hline
\end{tabular}




\begin{tabular}{|c|c|c|c|c|}
\hline $\begin{array}{l}\text { SL. } \\
\text { No. }\end{array}$ & Name of the Department & $\begin{array}{c}\text { Degrees } \\
\text { Conferred }\end{array}$ & $\begin{array}{c}\text { ICT related } \\
\text { Courses in the } \\
\text { Existing Syllabus }\end{array}$ & $\begin{array}{c}\text { Marks } \\
\text { Distribution }\end{array}$ \\
\hline \multirow[t]{9}{*}{12.} & \multirow[t]{9}{*}{$\begin{array}{l}\text { Department of Information } \\
\text { Science \& Library Man- } \\
\text { agement }\end{array}$} & \multirow[t]{9}{*}{$\begin{array}{l}\text { B.A. (Honors), } \\
\text { Masters, M.Phil, } \\
\text { PhD }\end{array}$} & $\begin{array}{l}\text { Course no. ISLM } \\
\text { 207- New Tech- } \\
\text { nologies \& Current } \\
\text { trends in Informa- } \\
\text { tion Systems }\end{array}$ & $\begin{array}{l}2^{\text {nd }} \text { Year } 3^{\text {rd }} \text { Se- } \\
\text { mester of B.A. } \\
\text { (Honors)- } 100 \\
\text { Marks (Theory) }\end{array}$ \\
\hline & & & $\begin{array}{c}\text { Course no. } 211 \\
\text { Computer Hard- } \\
\text { ware Maintenance } \\
\& \text { Troubleshooting }\end{array}$ & $\begin{array}{l}2^{\text {nd }} \text { Year } 4^{\text {th }} \text { Se- } \\
\text { mester of B.A. } \\
\text { (Honors)- } 100 \\
\text { Marks (Theory) }\end{array}$ \\
\hline & & & $\begin{array}{c}\text { Course no. } 314 \\
\text { Automation of } \\
\text { Information Insti- } \\
\text { tutions }\end{array}$ & $\begin{array}{l}3^{\text {rd }} \text { Year } 5^{\text {th }} \mathrm{Se}- \\
\text { mester of B.A. } \\
\text { (Honors)- } 100 \\
\text { Marks (Theory) }\end{array}$ \\
\hline & & & $\begin{array}{l}\text { Course no. } 318 \\
\text { Database Designs } \\
\text { and Applications }\end{array}$ & $\begin{array}{l}3^{\text {rd }} \text { Year } 6^{\text {th }} \mathrm{Se}- \\
\text { mester of B.A. } \\
\text { (Honors)- } 100 \\
\text { Marks (Theory) }\end{array}$ \\
\hline & & & $\begin{array}{l}\text { Course no. } 426 \\
\text { Information Net- } \\
\text { working \& Re- } \\
\text { source Sharing }\end{array}$ & $\begin{array}{l}\text { 4th Year } 8^{\text {th }} \text { Se- } \\
\text { mester of B.A. } \\
\text { (Honors)- } 100 \\
\text { Marks (Theory) }\end{array}$ \\
\hline & & & $\begin{array}{l}\text { Course no. } 427 \\
\text { Analysis and De- } \\
\text { sign of Informa- } \\
\text { tion Systems }\end{array}$ & $\begin{array}{l}\text { 4th Year } 8^{\text {th }} \text { Se- } \\
\text { mester of B.A. } \\
\text { (Honors)- } 100 \\
\text { Marks (Theory) }\end{array}$ \\
\hline & & & $\begin{array}{c}\text { Course no. } 503 \\
\text { Internet Studies \& } \\
\text { Web design }\end{array}$ & $\begin{array}{l}\text { M.A.- } 50 \text { Marks } \\
\text { (Theory) }\end{array}$ \\
\hline & & & $\begin{array}{l}\text { Course no. } 504 \\
\text { Information Re- } \\
\text { trieval Techniques }\end{array}$ & $\begin{array}{l}\text { M.A.- } 50 \text { Marks } \\
\text { (Theory) }\end{array}$ \\
\hline & & & $\begin{array}{l}\text { Course no. } 506 \\
\text { Library software } \\
\text { packages and ap- } \\
\text { plications }\end{array}$ & $\begin{array}{l}\text { M.A.- } 50 \text { Marks } \\
\text { (Theory) }\end{array}$ \\
\hline 13. & $\begin{array}{l}\text { Department of Theatre and } \\
\text { Music }\end{array}$ & $\begin{array}{l}\text { B.A. (Honors), } \\
\text { Masters, M.Phil, } \\
\text { PhD }\end{array}$ & No & - \\
\hline 14. & Department of Linguistics & $\begin{array}{l}\text { B.A. (Honors), } \\
\text { Masters, M.Phil, } \\
\text { PhD }\end{array}$ & $\begin{array}{l}\text { No } \\
\text { ( But has funda- } \\
\text { mental computer } \\
\text { training for stu- } \\
\text { dents of the de- } \\
\text { partment) }\end{array}$ & - \\
\hline 15. & $\begin{array}{l}\text { Department of World Re- } \\
\text { ligions }\end{array}$ & $\begin{array}{l}\text { B.A. (Honors), } \\
\text { Masters, M.Phil, } \\
\text { PhD }\end{array}$ & & \\
\hline
\end{tabular}

Source: Compiled from the Syllabus of departments of Faculty of Arts, University of Dhaka and visit to 15 departments of Faculty of Arts. 
It is clear from the above table that out of 15 departments only 4 departments offer more or less ICT related courses. It is very frustrating that 11 departments have no ICT related courses. Though some surveyed departments wish to introduce ICT course in their syllabus soon but in reality it will take time to introduce the course as it involves administrative process. It is also clear from the above table that the Department of Information Science \& Library Management is offering the largest number of ICT related courses among the surveyed departments. However the department is offering ICT courses that are mainly theoretical. Practical courses should be included into the curriculum to ensure students efficiency with the technology. Another positive picture is that Department of Islamic Studies is offering 3 courses on ICT to its students which are very effective and deserves appreciation. They offer Basic to Advanced level computer literacy course to its students. Besides Department of Sanskrit and Department of Pali and Buddhist Studies offer one course on ICT for their students which also deserves appreciation.

Integrating ICT into the university curriculum is not an overnight process. It requires careful planning, cooperation and coordination among the faculties, departments and institutes, cooperation among the ICT professionals and faculty members and cordial support from university administration. Efforts should be made by the authority to integrate ICT into the curriculum of all the departments of the University of Dhaka. The author of this paper suggests the ways to integrate ICT into the curriculum of the Faculty of Arts which could also be taken to integrate ICT into the curriculum of other faculties.

Before we make a plan to introduce the ICT into the curriculum, we should assess the existing ICT infrastructure facilities at the 15 departments of the Faculty of Arts. Table 3 illustrates the existing status of ICT infrastructure of the 15 departments.

Table 3: Status of ICT infrastructure of departments of Faculty of Arts

\begin{tabular}{|c|l|l|l|l|l|}
\hline $\begin{array}{l}\text { SL. } \\
\text { No. }\end{array}$ & $\begin{array}{l}\text { Name of the } \\
\text { Department }\end{array}$ & $\begin{array}{l}\text { Projector } \\
\text { in the } \\
\text { Class } \\
\text { Room }\end{array}$ & $\begin{array}{l}\text { Computer } \\
\text { Lab }\end{array}$ & $\begin{array}{c}\text { No. of } \\
\text { Computers in } \\
\text { the } \\
\text { Lab/Library }\end{array}$ & $\begin{array}{l}\text { Internet Facility } \\
\text { for the Students }\end{array}$ \\
\hline 1. & Department of Bengali & No & No & No & No \\
\hline 2. & Department of English & Yes & $\begin{array}{l}\text { No. But its } \\
\text { library has } \\
\text { computers } \\
\text { for students. }\end{array}$ & 05 & Yes \\
\hline 3. & Department of Arabic & No & No & No & No \\
\hline 4. & $\begin{array}{l}\text { Department of Persian } \\
\text { Language \& Literature }\end{array}$ & No & No & No & No \\
\hline 5. & Department of Urdu & No & No & No & No \\
\hline 6. & $\begin{array}{l}\text { Department of San- } \\
\text { skrit }\end{array}$ & No & Yes & 03 & Limited access \\
\hline 7. & $\begin{array}{l}\text { Department of Pali } \\
\text { and Buddhist Studies }\end{array}$ & No & No & No & No \\
\hline 8. & Department of History & Yes & No & No & No \\
\hline 9. & $\begin{array}{l}\text { Department of Phi- } \\
\text { losophy }\end{array}$ & No & $\begin{array}{l}\text { No. But its } \\
\text { library has } \\
\text { computer } \\
\text { for students. }\end{array}$ & 01 & Limited \\
\hline 10. & $\begin{array}{l}\text { Department of Islamic } \\
\text { Studies }\end{array}$ & No & Yes & 25 & Yes \\
\hline 11. & $\begin{array}{l}\text { Department of Islamic } \\
\text { History and Culture }\end{array}$ & Yes & No & No & No \\
\hline & & & & \\
\hline
\end{tabular}




\begin{tabular}{|c|l|l|l|l|l|}
\hline $\begin{array}{l}\text { SL. } \\
\text { No. }\end{array}$ & $\begin{array}{l}\text { Name of the } \\
\text { Department }\end{array}$ & $\begin{array}{c}\text { Projector } \\
\text { in the } \\
\text { Class } \\
\text { Room }\end{array}$ & $\begin{array}{c}\text { Computer } \\
\text { Lab }\end{array}$ & $\begin{array}{c}\text { No. of } \\
\text { Computers in } \\
\text { the } \\
\text { Lab/Library }\end{array}$ & $\begin{array}{c}\text { Internet Facility } \\
\text { for the Students }\end{array}$ \\
\hline 12. & $\begin{array}{l}\text { Department of Infor- } \\
\text { mation Science \& Li- } \\
\text { brary Management }\end{array}$ & Yes & Yes & 15 & Yes \\
\hline 13. & $\begin{array}{l}\text { Department of Theatre } \\
\text { and Music }\end{array}$ & No & No & No & No \\
\hline 14. & $\begin{array}{l}\text { Department of Lin- } \\
\text { guistics }\end{array}$ & Yes & Yes & 11 & Yes \\
\hline 15. & $\begin{array}{l}\text { Department of World } \\
\text { Religions }\end{array}$ & Yes & No & No & No \\
\hline
\end{tabular}

Source: Field visit.

As evident from the above table it is very frustrating that in this age of information \& communication technology most of the departments of the Faculty of Arts do not have computer facilities for the students. Out of 15 departments only 4 have their own computer lab. It is worth mentioning that Department of Islamic Studies has the largest computer lab in the Faculty of Arts. Out of 15 departments only 6 have projector in the class room which is unexpected. Without a computer lab it is illogical to think that students of the respective departments will be able to exploit the information technology for development and will become lifelong learners.

\section{Integration of ICT into the Curriculum}

To ensure effective and successful ICT integration, an Information \& Communication Technology Curriculum Integration (ICTCI) task force should be formed. Vice Chancellor of the university should be the Chairperson of that task force. Dean of the Faculty of Arts should be the Vice Chairman. Chairperson from each department should be the Executive Member of the task force. They will be liable to integrate ICT in their respective department. Director from the Institute of Information Technology will work as Executive Member to help in designing the curriculum. Industry representative should also be part of the task force as Executive Member for the standards or employability of the students. Thus the total task force could be represented in the following way:

1. Chairperson

2. Vice- Chairperson

3. Executive Members

After the formation of the task force activities should be distributed to all members of the task force. First Chairperson of each department with the help of other teachers will propose ICT curriculum for their respective department and send it to the Dean of the faculty to review it thoroughly. After thorough revision by the Dean it will be presented at the General Meeting of ICTCI task force for approval. After it is approved by the task force it would be finally printed and distributed to all respective students and teachers. Information \& Communication Technology Curriculum Integration (ICTCI) task force should continuously work for the successful integration of ICT, and time to time revision of the curriculum. Similar structure could be followed to integrate ICT into curriculum of other faculties of the University of Dhaka.

The introduction of information and communication technologies (ICTs) and the expansion of their use in the educational field have forced the creation of training programs for faculty on the use of ICTs. The main obstacle for designing any ICT training program has to do with the lack of information on the actual needs of faculty members and the type of format that should be utilized 
for those training needs (Galanouli, Murphy, \& Gardner, 2004). An adequate way to learn about those needs is to analyze the studies that have made a correct diagnosis of faculty's training needs in the field of ICTs and the characteristics of the specific training that they receive (Lareki, 2010). ICTCI task force should ensure teachers training on ICT. Because without comprehensive training on ICT knowledge it is illogical to think that ICT integration into curriculum will bring positive result.

The task force should keep in mind that in integrating ICT into the curriculum they could face some barriers from the teachers' parts. It is logical that not all teachers' of the Faculty of Arts would accept the integration positively and would not have the skills to teach the students. AlSenaidi et al (2009) in their paper mentioned the barriers to technology adoption at the international level for teachers across the education levels given by Becta (2004) after reviewing studies on related literatures:

(a) A very significant determinant of teachers' levels of engagement in ICT is their level of confidence in using the technology. Teachers who have little or no confidence in using computers in their work will try to avoid them altogether.

(b) Levels of access to ICT are significant in determining levels of use of ICT by teachers.

(c) Inappropriate training styles result in low levels of ICT use by teachers.

(d) Teachers are sometimes unable to make full use of technology because they lack the time needed to fully prepare and research materials for lessons.

(e) Technical faults with ICT equipment are likely to lead to lower levels of ICT use by teachers.

(f) Resistance to change is a factor which prevents the full integration of ICT in the classroom.

(g) Teachers who do not realize the advantages of using technology in their teaching are less likely to make use of ICT.

(h) There is little evidence that supports the view that age affects levels of teachers' ICT use. There is some evidence to suggest that teachers' gender has an effect on the degree to which they use ICT, with male teachers making more use of ICT than female teachers, and with female teachers reporting greater levels of computer anxiety than male teachers.

It has been argued that there are close relationships between many of the identified barriers to ICT use. Any factors influencing one barrier are likely to influence several other barriers. For example, teacher confidence is directly affected by levels of personal access to ICT, levels of available technical support and the amount and type of training available, all of which can be seen as barriers to ICT themselves (Ertmer, 1999).

No need to think that the task force would face all these barriers mentioned above. ICTCI should work close with the teachers' to reduce the barriers as well as should ensure comprehensive training before implementing the curriculum.

Training of the teachers should be based on practical demonstration on the uses of information \& communication technology in teaching and learning and the application of ICT in the class room. Teachers training could be conducted by the Institute of Information Technology, University of Dhaka or in partnership with the British Council Bangladesh office.

After successful completion of the teachers' training it is expected that a teacher will be able to: 
1. research, analyze and interpret current policy documents on teacher competencies in ICT

2. research, analyze and apply syllabus prescriptions on the embedding of ICT outcomes in teaching and learning in their respective subject

3. select information and communication technology-based learning strategies and resources to meet student learning needs

4. create learning experiences in which students use information and communication technologies to research, interpret, analyze, communicate and represent knowledge.

5. demonstrate an awareness of a range of learning technology resources and how they can be integrated constructively and creatively with other resources in the curriculum area

6. deploy learning technologies to assist students develop critical learning skills

7. design learning experiences in which students actively use ICT to research, interpret, analyze, communicate and represent knowledge and understanding

8. help students become lifelong learners.

When teachers' training is completed successfully, integration of ICT into the curriculum starts. At this moment a general ICT curriculum should be taken by all departments lacking ICT integration into their curriculum. Some minor modifications or changes may be made if required. However before final integration of ICT into the curriculum ICT infrastructure of the departmental class room and ICT skills of the teachers' should be assessed. After it is found that the departmental ICT infrastructure is satisfactory to run the courses on ICT and there are teachers who could teach the course then final ICT integration can be implemented. If it is found that there are some departments that have inadequate ICT infrastructure then necessary initiatives should be taken to promote the ICT infrastructures in those departments. In case of the Faculty of Arts as the survey conducted by the author already revealed that 11 departments require computer lab and 9 departments require multimedia projector.

The overriding purpose of ICT integration into curriculum is to create an environment for interaction among teachers and students and to harness the technological facilities. To meet up this purpose multi-media projector should given to all departments those not using multimedia projector as well as sophisticated centralized video conferencing equipments can be installed at the Faculty of Arts office. It should be mentioned here that it is not possible for Faculty of Arts administration to provide up-to-date video conferencing equipment to all departments and offer technical and staff support for its maintenance instead it is possible to install and offer support centrally. Thus if any department wants to conduct video conference session could contact with the Faculty office and arrange it according to their requirements.

Faculty of Arts could take ICT integration into curriculum as a one year project. First month of the project is to be spent to form the ICTCI task force. After the task force is formed assessment of the ICT infrastructure of the departments and skills of the teachers should be assessed and necessary initiatives to create an environment to integrate ICT into the curriculum should be taken. Three months could be spent for teachers training and ICT infrastructure improvements. After teachers training and necessary improvements of the infrastructures are done, designing of the curriculum starts. Designing and reviewing the curriculum before sending it to the Dean's office and to the Academic Council of the University of Dhaka three months could be given. The rest of the six months could be needed to finally integrated into the curriculum and formally start the course as this requires some formal approval from the different academic bodies of the University of Dhaka. 
Table 4 shows a sample ICT Curriculum which could be taken into consideration while designing the curriculum.

\section{Table 4: Sample ICT Curriculum}

\begin{tabular}{|c|c|c|}
\hline Title & Brief Contents & Learning Outcomes \\
\hline $\begin{array}{l}\text { Basic } \\
\text { Hardware }\end{array}$ & $\begin{array}{l}\text { i) Types of Computers } \\
\text { ii) Function of various } \\
\text { computers } \\
\text { iii) Factors influencing } \\
\text { while purchasing of } \\
\text { computers } \\
\text { iv) Basic hardware trou- } \\
\text { bleshooting and mainte- } \\
\text { nance }\end{array}$ & $\begin{array}{l}\text { Students should be able to: } \\
\text { i. } \\
\text { identify types of computers, how they process in- } \\
\text { formation and how individual computers interact } \\
\text { with other computing systems and devices } \\
\text { ii. } \\
\text { identify the function of computer hardware com- } \\
\text { iii. } \quad \text { identify the factors that go into an individual or } \\
\text { iv. } \\
\text { v. decision on how to purchase computer equipment } \\
\text { identify how to maintain computer equipment and } \\
\text { vi. }\end{array}$ \\
\hline Windows & $\begin{array}{l}\text { Set-up windows, Install } \\
\text { software, basic windows } \\
\text { use. }\end{array}$ & $\begin{array}{l}\text { Students should be able to: } \\
\text { i) identify what an operating system is and how it } \\
\text { works, and solve common problems related to operat- } \\
\text { ing systems } \\
\text { ii) manipulate and control the Windows desktop, files, } \\
\text { and disks } \\
\text { iii) identify how to change system settings, install and } \\
\text { remove software } \\
\text { iv) format the hard disk, Set up new windows } \\
\text { xp/vista. } \\
\text { create New folder, delete existing folder }\end{array}$ \\
\hline $\begin{array}{l}\text { Windows } \\
\text { Office }\end{array}$ & $\begin{array}{l}\text { Basic use of MS Word, } \\
\text { Excel, Power Point, Data } \\
\text { Access, Front Page and } \\
\text { other softwares. }\end{array}$ & $\begin{array}{l}\text { Students should be able to: } \\
\text { i) use Microsoft office package. } \\
\text { use various educational software }\end{array}$ \\
\hline Internet & $\begin{array}{l}\text { Services available } \\
\text { through internet, search } \\
\text { techniques of various } \\
\text { search engines, evaluate } \\
\text { search strategy and } \\
\text { search results as well as } \\
\text { search engines, basic e- } \\
\text { mail function, subscribe } \\
\text { to subject related list- } \\
\text { serv, create online group, } \\
\text { use online research tools, } \\
\text { blogging, use social } \\
\text { networking tools, use } \\
\text { selected e-learning plat- } \\
\text { form and so on. }\end{array}$ & $\begin{array}{l}\text { Students should be able to: } \\
\text { i) state the various services available through inter- } \\
\text { net } \\
\text { ii) use advanced search techniques for various search } \\
\text { engines on the WWW } \\
\text { iii) evaluate the search strategy and the search results } \\
\text { iv) perform basic e-mail function } \\
\text { v) subscribe to listservs } \\
\text { vi) practice basic e-mail netiquette } \\
\text { vii) create online blogs } \\
\text { viii) use available online research \& social networking } \\
\text { tools and selected e-learning platform and so } \\
\text { on }\end{array}$ \\
\hline
\end{tabular}




\begin{tabular}{|c|c|c|}
\hline Title & Brief Contents & Learning Outcomes \\
\hline $\begin{array}{l}\text { Web } \\
\text { Browser }\end{array}$ & $\begin{array}{l}\text { Introduction to various } \\
\text { web browsers, use of } \\
\text { various web browsers. }\end{array}$ & $\begin{array}{l}\text { Students should be able to: } \\
\text { i) skim and scan for information on a web page } \\
\text { ii) set options and preferences to customize desktop } \\
\text { download and use plug-ins such as Adobe } \\
\text { Acrobat Reader and RealPlayer for Digital } \\
\text { Library Collections } \\
\text { iii) download software from the net } \\
\text { iv) save web file to hard drive and/or pen drive } \\
\text { v) print web page } \\
\text { vi) use internet option } \\
\text { vii) use bookmark } \\
\text { save image file etc. }\end{array}$ \\
\hline Networks & Network Fundamentals & $\begin{array}{l}\text { Students should be able to: } \\
\text { i .Identify network fundamentals and the benefits and } \\
\text { risks of network computing } \\
\text { ii. Identify the relationship between computer net- } \\
\text { works, other communications networks. }\end{array}$ \\
\hline $\begin{array}{l}\text { Social } \\
\text { and Ethi- } \\
\text { cal Issues }\end{array}$ & $\begin{array}{l}\text { Basic concepts such as } \\
\text { computer crime and } \\
\text { fraud, equity, intellectual } \\
\text { ownership, privacy of } \\
\text { information, links be- } \\
\text { tween automation and } \\
\text { unemployment, and } \\
\text { computer security (theft, } \\
\text { hacking, viruses) }\end{array}$ & $\begin{array}{l}\text { Students should be able to demonstrate an understanding } \\
\text { of (UNESCO, 2002): } \\
\text { i. the benefits and drawbacks of computer use to } \\
\text { society in general; } \\
\text { ii. } \quad \text { the economic advantages and disadvantages of } \\
\text { the use of computers; } \\
\text { iii. } \quad \begin{array}{l}\text { the ethical questions that have arisen as a result of } \\
\text { computer use with }\end{array} \\
\text { iv. } \quad \text { respect to privacy aspects, copyright issues and } \\
\text { computer viruses; } \\
\text { the current situation and trends in computing } \\
\text { vi. } \quad \begin{array}{l}\text { against the background } \\
\text { of past developments in a) hardware; b) software; } \\
\text { and c) ways of operating. }\end{array}\end{array}$ \\
\hline
\end{tabular}

This marks distribution of Information Technology course is not final. The departments themselves should design it in their own way. Table 5 shows a sample marks distribution on ICT course:

Table 5: Sample Marks distribution of Information Technology Course

\begin{tabular}{|c|c|}
\hline Title & Marks \\
\hline Class Test & 10 \\
\hline Presentation & 05 \\
\hline Midterm & 10 \\
\hline Practical & 35 \\
\hline Semester Final & 40 \\
\hline Total & $\mathbf{1 0 0}$ \\
\hline
\end{tabular}




\section{Barriers to ICT Integration}

Several problems impede the integration of ICT into the curriculum of departments of Faculty of Arts, University of Dhaka actually the university curriculum of Bangladesh. Some of these are discussed below:

i) absence of academic information technology integration initiatives from the University Grants Commission of Bangladesh.

ii) administrative complexity in integrating information technology into the university curriculum and as a whole its introduction in the national level.

iii) low level of national and international integration

iv) lack of infrastructure support

v) lack of proper planning and decisive management

vi) lack of government support and initiatives

vii) lack of awareness program regarding the importance of information technology at the national level

viii) absence of systematic management support

ix) shortage of personnel

$\mathrm{x}$ ) lack of professional training for the faculty members

xi) shortage of funds

\section{Recommendation}

A few suggestions are put forward which can be taken into considerations to integrate ICT into the university curriculum and to promote ICT activities at the national level.

1. University authority should urgently form Information Communication and Technology Curriculum Integration (ICTCI) task force. This task force will work dedicatedly for the successful and effective ICT integration into the university curriculum.

2. University authority should ensure availability of adequate technical infrastructure (e.g. hardware, software, Internet access) in every departments of the respective university.

3. Sife et al. (2009) cited by Kajuna (2009) have indicated that institutions of higher education should diversify sources of funds to have a wide financial base. The issue of shortage of technology equipment, especially computers, posed a tremendous problem. Given the fact that technology is very expensive and, as pointed out earlier, the government cannot fully support the universities, the universities should seek ways to complement what funds they do receive from the government. Dependency on foreign donors has its limits and conditions that may not be favorable to the institutions. In that regard, Kajuna (2009) recommends the establishment of partnerships with local people and organizations, who are also stakeholders. These partners may include parents, alumni, business companies, Governmental Organizations (GOs), and Nongovernmental Organizations (NGOs). In some cases, the partnership may be done in exchange for expertise of the university. In line with this, the university may establish the technology fund, and the technology committee may find ways of mobilizing the general public to contribute to this fund or organize fundraising events. Priority should be given to the acquisition of more computers and teachers' professional development programs. 
Integrating ICT into University Curriculum

4. Dean, Faculty of Arts should support teaching staff in their efforts to design teaching methods that suit different types of learning styles with ICT.

5. University Grants Commission (UGC) of Bangladesh should take bold initiative in directing the higher educational institutions to integrate ICT in the curriculum by providing financial and other support to integrate ICT at the initial stage.

6. Government should form National Information and Communication Technology Curriculum Integration (NICTCI) task force to promote ICT activities at the national level as well as to monitor national ICT activities.

7. UGC should organize national and international seminars, conferences, symposiums, short trainings on ICT to ensure ICT skills of teachers and students of various universities of Bangladesh.

8. Government should allocate sufficient fund to implement ICT activities at the national level.

9. University authority should offer sufficient administrative and technical support services for teachers and learners.

10. Proper planning and decisive management is a must in implementing and integrating ICT at the national level and into the university curriculum of Bangladesh.

\section{Conclusion}

The adoption of ICT at universities is often poorly implemented and is based on unfounded optimism (Taylor, 1998). Research by Becta (2004) has found serious obstacles to fully integrating technology into the teaching and learning processes in higher education. Technologies have great potential for knowledge dissemination, effective learning, and efficient education services. Yet, if the educational policies and strategies are not right, if ICT-in-education policies are not well thought out, and if the prerequisite conditions for using these technologies are not met concurrently, this potential will not be realized.

Status of integration of ICT into the curriculum of the departments of Faculty of Arts is not satisfactory at all. Effective initiatives are required to integrate ICT in the curriculum of the departments not having ICT courses. It should be noted here that Faculty of Arts established a computer center named "Arts Computer Center" in 2001. The center has 13 computers at this moment used by the limited students of Faculty of Arts enrolled in the computer courses conducted by the center.

Government of Bangladesh pledged to convert Bangladesh into 'Digital Bangladesh' by 2021 which is the 50th anniversary of the independence of Bangladesh. Government has already taken a good number of programs to implement ICT related activates in almost all government sector as well as planning to spread ICT service to all. Government is planning to promote ICT infrastructure in all educational institutions. Though current ICT infrastructure of the public universities are not so praise worthy and still there are lack of concentration on ICT integration into the curricula. Without ensuring proper ICT facility for the university students who are considered the future of the nation and without making them ICT literate the dream to make Digital Bangladesh is far way. 


\section{References}

Al-Senaidi, S., Lin, L. \& Poirot, J. (2009).Barriers to adopting technology for teaching and learning in Oman. Computers \& Education, 53(3), 575-590.

Asiatic Society of Bangladesh. (2006). Banglapedia. Retrieved March 06, 2010 from http://www.banglapedia.org/httpdocs/HT/C 0328.HTM

Bangladesh Bureau of Statistics (BBS). (2005). Household Income Expenditure Survey (Provisional). Dhaka.

Barron, A. E., Orwig, G. W., Ivers, K. S. \& Lilavois, N. (2001). Technologies for education: A practical guide (4th ed.). Greenwood Village, CO: Libraries Unlimited.

Blankson, J. (2004). The use of technology by faculty members at Ohio University. Doctoral dissertation, College of Education of Ohio University.

British Educational Communications and Technology Agency (Becta). (2004). A review of the research literature on barriers to the uptake of ICT by teachers. Retrieved March 05, 2010 from http://research.becta.org.uk/index.php?section=rh\&rid=13642

Ertmer, P. E. A. (1999). Examining teachers' beliefs about the role of technology in the elementary classroom. Journal of Research on Computing in Education, 32 (1), 54-72.

Galanouli, D., Murphy, C., \& Gardner, J. (2004). Teachers' perceptions of the effectiveness of ICTcompetence training. Computers \& Education, 43(1-2), 63-79.

Haddad, W.D. (2007). ICT for education: Decision makers' essentials. Retrieved March 05, 2010 from http://www.ictinedtoolkit.org/icttool/usere/pdfs/ICTs_for_Education_Essentials.pdf

Kajuna, L.W. (2009). Implementation of technology integration in higher education: A case study of the University of Dar-es-Salaam in Tanzania. Doctoral dissertation, College of Education of Ohio University.

Kok, A. (2006). ICT integration into classrooms- A literature review. Retrieved March 07, 2010 from http://www.eadl.org/documents/2006/ICT\%20Integration\%20into\%20Classrooms_KOK.pdf

Lareki, A., Martínez de Morentin, J. I. \& Amenabar. (2010).Towards an efficient training of university faculty on ICTs. Computers \& Education, 54(2), 491-497.

Omwenga, E. I. (2005). Pedagogical issues and e-learning cases: Integrating ICTs into teaching and learning process. Retrieved January 10, 2008 from http://iucea.org/downloads/5.\%20Pedagogical\%20Issues\%20and\%20e-Learning\%20Cases.doc

Rahman, C. M. (2008). IT education in Bangladesh. Retrieved January 10, 2008 from http://www.sdnpbd.org/sdi/issues/education/it_education_in_bangladesh.php

Taylor, P. (1998). Institutional change in uncertain times: Lone ranging is not enough. Studies in Higher Education, 23, 269-278.

Tinio, V.L. (2003). ICT in education. Retrieved January 10, 2008 from http://www.apdip.net/publications/iespprimers/ICTinEducation.pdf

UNESCO. (2002).Information \& communication technology in education: A curriculum for schools and program of teacher development. France.

University of Dhaka. (2008). University of Dhaka prospectus. Dhaka.

University of Dhaka. (2006-2007). Annual report of the University of Dhaka. Dhaka. 


\section{Biography}

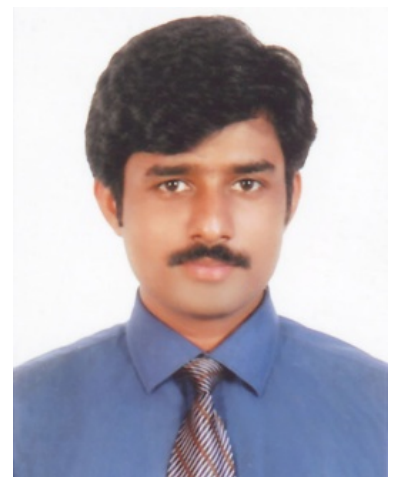

Nafiz Zaman Shuva is Lecturer of the Department of Information Science \& Library Management, University of Dhaka. Nafiz secured 1 st class 1 st position in both his BA (Honours) and Masters from the Department of Information Science \& Library Management, University of Dhaka, Bangladesh. Currently Nafiz is Erasmus Mundus Scholar for the 2009-2011 academic sessions. He has more than 10 research publications in his credit. Nafiz is the founder president of the Bangladesh Association of Young Researchers (BAYR). He is one of the ASIS\&T international paper contest winner 2004. Recently Nafiz presented a paper on "Promoting use of electronic resources in libraries of Bangladesh: A developing country perspective" at the Electronic Resources and Libraries Conference -2010 in Austin, Texas. His research interest includes information and communication technology, digital library system development, mobile applications in libraries and education institutions, e-government and its related aspects. 